\title{
The Pomeranian National Institute for the Deaf and Speech-Impaired in Wejherowo, 1921-1939. Introduction to research
}

\begin{abstract}
In the interwar period there was an intensive development of the theory and practice of pedagogy in Poland. At that time new schools and centers for children with disabilities were created, including for the deaf-mute. In 1921 the Pomeranian National Institute for the deaf and mute was established in Wejherowo. The paper presents the circumstances of the institution's creation, its organization, rules of admission for pupils, curriculum and social life. Also provided is information on the authority of the Department and the teaching staff. In order to discuss these issues, source materials, stored in the Gdynia branch of the State Archive in Gdansk and held by the Educational-Instructional Centre for the Deaf Mute No. 2 in Wejherowo were used.
\end{abstract}

Keywords: history of special education, education and upbringing of the deaf and mute

Education of deaf and speech-impaired persons is the oldest field of special education in Poland. It is connected with the founding of the Warsaw Institute of Deaf and SpeechImpaired in 1817, the first institution educating deaf children in Poland. In 1842 it was transformed into an educational institution for the blind, and since then it has been called the Warsaw Institute of the Deaf, Speech-Impaired and the Blind. In the 19th century, following the example of the Warsaw institution, new institutions of this kind were established on Polish soil. The development of special education and special pedagogy was most intense during the interwar period, thanks to the efforts of outstanding educators and educational activists, led by Maria Grzegorzewska. It was then that the National Institute of Special Pedagogy, the first institution to educate teachers for the needs of special education, began its operations. However, this does not mean that in the interwar period it was possible to speak of meeting the real needs of people with disabilities in terms of education. The official statistics on deaf and speech-impaired people in Poland were not compiled until 1927, so all earlier data are only estimates. According to the Statistical Yearbook of the 
Republic of Poland of 1927, statistical data indicate that there were a total of 33,866 deaf and speech-impaired people in Poland at that time, including 15,018 women and 18,848 men $^{1}$. At the same time, data on education show that in the school year 1918/19 there were seven schools for the Deaf and speech-impaired children in Poland, serving 503 students, with 65 employed teachers ${ }^{2}$. Six years later, in 1925, only 800 girls and boys were taught at schools and institutions for the deaf and speech-impaired, out of a total of 4352 deaf and speech-impaired children of school age. They could get their education in 11 institutions operating in Warsaw (Institute of the Deaf, Speech-Impaired and the Blind, Municipal Afternoon School for the Deaf and Speech-Impaired, Deaf and Speech-Impaired School of the Society for the Care of Deaf and Speech-Impaired Jews), in Lviv (Institution for the Deaf and Speech-Impaired, Bardach Private School for Jewish children), in Poznań (National Institute for the Deaf and Speech-Impaired), in Kościan, Poznań Voivodeship (National Institute for the Deaf and Speech-Impaired), Łódź (School for Deaf and SpeechImpaired Christians no. 97, Jewish School of the Ezras-Ilmin Association), Wejherowo (Pomeranian National Institute for the Deaf and Speech-Impaired) and in Willa-Góra near Nowy Dwór (National Farming and Gardening School for the Deaf and SpeechImpaired) ${ }^{3}$. Until the outbreak of World War II, the situation changed little. According to Henryk Ryll, there were only 16 schools for deaf and speech-impaired children in Poland at that time, where 1333 children were taught and 121 teachers were employed ${ }^{4}$.

The Pomeranian National Institute for the Deaf and Speech-Impaired in Wejherowo was one of the few schools for deaf and speech-impaired people, which were functioning in the first years after Poland regained its independence. It is worth noting that the institution has been operating in Wejherowo until now as J. Siestrzyński Educational and Pedagogical Centre No. 2 for the Deaf. However, this institution was not yet a subject of a full monographic study. Therefore, this publication is a starting point to the research on the history of this institution and an attempt to describe its organisation and activities in the interwar years. For this purpose, source materials collected in the National Archive in Gdańsk, Gdynia Branch, as well as occasional materials published by the Educational and Pedagogical Centre for the Deaf in Wejherowo and unpublished materials held by the Centre were used.

1 "Statystyka", Nauczyciel Gtuchoniemych i Niewidomych, 1928, issue 2, p 28.

2 TUŁODZIECKI, W., "Stan i potrzeby szkolnictwa dla głuchoniemych w Polsce", Nauczyciel Gtuchoniemych i Niewidomych, 1932, issue 1.

${ }^{3}$ HELLMANN, J., "Stan i potrzeby szkolnictwa specjalnego w Polsce”, Szkoła Specjalna, 1924/25, issue 1 , p. 6-7.

${ }^{4}$ RYLL, H., "Stan szkolnictwa specjalnego w Polsce w ostatnim pięcioleciu”, Szkoła Specjalna, 1938/39, issue 15 , p. $153-155$. 


\section{Establishment of the Pomeranian National Institute for the Deaf and Speech-Impaired in Wejherowo}

After World War I, German schools for deaf children in Malbork and Człuchów ended up outside the liberated Polish state. There was therefore a need to establish a school for the deaf and speech-impaired children of the Pomeranian region. The National Starost Office in Torun decided to establish the Pomeranian National Institute for the Deaf and Speech-Impaired in Wejherowo on the 1st of September 1921. The school was to be located on the premises of the liquidated psychiatric hospital ${ }^{5}$. The psychiatric hospital was founded in 1883. After Poland regained independence, Dr Edward Kawczyński was its first Polish director, who took over an almost empty facility in 1920. The German authorities transferred the afflicted German soldiers and prisoners of war to other facilities, leaving only Polish citizens in Wejherowo. That is why the National Starost Office in Torun decided to set up other care and educational institutions there in order to avoid handing them over for use as army barracks. The implementation of these goals started with the organisation of the Institute for the Deaf and Speech-Impaired ${ }^{6}$. The handover report was approved on the 13th of December 1921. The facility's assets consisted of cash in the amount of 95,100 marks and 3,739 marks in the facility's account, which totalled 98,842 marks ${ }^{7}$. The handover of all equipment, formerly owned by the psychiatric institution, took place on the 16 th of December $1922^{8}$.

On the 1st of January 1923, Dr Stanisław Gąsowski took over the management of the hospital from the director of the National Medical Institute for Mentally Ill, Dr E. Kawczyński, for the duration of the liquidation of the hospital, until the completion of activities pertaining to the organisation of the National Institute for the Deaf and Speech-Impaired, as well as other planned institutions (for the blind, people with disabilities and anaemics) in Wejherowo'. This year the National Social Welfare Organisations was established as a group of institutions located in Wejherowo on Sobieskiego Street. The Organisations were owned by the Pomeranian Voivodship Municipal Union, under the control of the voivodeship authorities, overseen by the Ministry of the Interior ${ }^{10}$. The state of the National Social Welfare Organisations changed at different times, and apart from the National Institute for the Deaf and Speech-Impaired, it eventually included: Medical Institute for Mentally Ill, Department of Siberian Children, Pomeranian Chamber of Agriculture, Immigration Office

${ }_{5}$ Historia Ośrodka Szkolno-Wychowawczego $n r 2$ dla Gtuchych im. J. Siestrzyńskiego w Wejherowie, Wejherowo 1991, p. 7.

${ }^{6}$ KOTEWICZ, J., Historia zakładu dla Gluchych $w$ Wejherowie. Typescript held by the Educational and Pedagogical Centre no. 2 Library in Wejherowo.

${ }^{7}$ National Archive in Gdańsk, Gdynia Branch: (hereinafter NAGGB), Fonds 223, National Social Welfare Organisations in Wejherowo, sign. 9, c. 17.

8 Ibidem, c. 24.

9 Ibidem, c. 1-2.

${ }^{10}$ NAGGB, Fonds 223, National Social Welfare Organisations in Wejherowo, sign. 3, c. 145. 
in Gdynia with temporary seat in Wejherowo, Primary School and Educational Institute for Morally Neglected Children and Special School for Mentally Disabled Children ${ }^{11}$. Following these developments, on the 8th of January 1925, the Voivodship Assembly passed a resolution setting the Rules and Regulations for the Pomeranian National Institute for the Deaf and Speech-Impaired in Wejherowo, approved by a decree of the Ministry of the Interior from the 27th of April $1925^{12}$. The Rules and Regulations defined all important aspects of the facility's functioning, such as: scope of operation, administration, staff and professional relations, the work of the pedagogical board, rules of admission, curriculum, medical and educational care and maintenance costs. In accordance with the regulations, the Institute was a boarding school, and its main task was "to educate and raise deaf and speech-impaired children according to their mental capacity and to prepare them for vocational education ${ }^{13}$." The institution was run by the National Department (or the National Starost) in accordance with the regulations and resolutions of the Voivodship Assembly and supervised by the Pomeranian School District, whose tasks included the approval of the curriculum and teaching plan, oversight over teaching and upbringing, as well as visiting and supporting the institution in order to maintain an appropriate level of education. The direct supervision over the institution was entrusted to the director, whose tasks were defined by the Voivodeship Assembly and the official instructions. The Director's task was to keep in touch with the National Starost Office, district and municipal authorities, parents of the students, the Voivodship Office, the Pomeranian School District and the Ministry of Education through the National Starost ${ }^{14}$.

\section{Facilities}

According to the inventory documents of the Institute's buildings from 1935, it can be seen that the facility comprised: Pavilion D, where the chapel was located, Pavilion 14, where teachers' residences were located, along with a hospital for the students. Pavilion 10 was a boarding house for deaf boys, and Pavilion 12 hosted a boarding house for deaf girls. The school was located in Pavilion 8, while workshops, joineries and bookbinding rooms were located in pavilion 2. It is also worth noting that Pavilions 11 and 9 were occupied by the boarding houses of the Educational Institute, and its school was located in Pavilion 4, while Pavilion 6 housed a school and boarding school for the mentally handicapped children. There was also a school playing field on the premises ${ }^{15}$. The pavilions

11 Ośrodek Szkolno-Wychowawczy $n r 2$ dla Niestyszących im. J. Siestrzyńskiego w Wejherowie, Wejherowo 2001, p. 11.

12 "Regulamin dla Pomorskiego Krajowego Zakładu dla Głuchoniemych w Wejherowie", Dziennik Urzędowy Województwa Pomorskiego, issue 15, year V, Toruń, 13 VI 1925.

13 Ibidem, p. 67.

14 Ibidem, p. 68.

15 NAGGB, Fonds 223, National Social Welfare Organisations in Wejherowo, sign. 12, c. 131-136. 
were not very suitable for school purposes, because they had very few windows and their layout with large, connecting rooms did not favour educational work or physical development of children. Block 8, where the school was located, had to be adapted to the requirements of teaching by dividing the halls into smaller classrooms. Despite these efforts, four classrooms remained connected to other rooms. Moreover, the school pavilion did not have a recreation room or a gymnasium. During breaks, on sunny days children went to the school yard, while in winter and other days they stayed in classrooms all the time. Physical education classes were held in the school yard and in the winter, they were moved to the local secondary school's gymnasium ${ }^{16}$.

The equipment in the boarding house was very simple and modest: long tables in the dining room and day room, iron beds and closets in bedrooms. These rooms were very unsightly, dark and gloomy ${ }^{17}$.

\section{Admission of children to the institution}

In the first year of its activity nearly 80 students were admitted to the Institute. In the following years the number of children admitted to the institution increased and amounted to about 120 students $^{18}$.

The rules of admission were stated in detail in the Institute's Rules and Regulations. The school admitted deaf and speech-impaired children, who were required to attend a special school. Before the child was admitted to the Institute, the local authorities should submit a birth certificate, a certificate of baptism, a smallpox vaccination certificate and an official statistical interview. Children were usually admitted at the beginning of the subsequent school year, but the National Starost could make a special exception and set a different date. The National Starost could also, in special circumstances, exempt a deaf child from attending the Institute, but only for a maximum period of one year. The exemption decision had to be communicated to the parents or guardians of the child. A copy of the decision was also submitted to the School District Superintendent. Archive materials contain a confirmation of strict compliance with the rules laid down in the regulations. The large number of letters exchanged between the local authorities and the management of the Institute, parents and doctors collected in the archives mainly concerns deferrals from compulsory schooling, the health of deaf children, costs of living or accommodation ${ }^{19}$. Parents or guardians were ordered to bring their child to the Institute at least 6 weeks before the date of admission. The National Starost communicated the deadline for placing

\footnotetext{
${ }^{16}$ KOTEWICZ, J., op. cit.

17 Historia Ośrodka..., op. cit., p. 16.

18 Ośrodek..., op. cit., p. 16.

19 NAGGB, Fonds 72, School Inspectorate in Wejherowo in years [1911] 1918-1939, sign. 343, vol. 1 and 2, passim.
} 
the child in the Institute to the parents or guardians of the deaf child, informing them that the child should be brought in clean, with underwear and clothes as stated in the regulations. The manager of the Institute could, in consultation with the parents or guardians, arrange for the child to be brought to the Institute by teaching staff or other appropriate persons. If the parents or guardians refused to bring the child to the Institute or if the child was not brought in within 4 weeks of the deadline for admission to the Institute, the National Starost was obliged to submit a request to the School District authorities to bring the student to the school involuntarily. The Institute placed its youngest pupils - children aged from 1 to 4 - in the boarding house. Older children were placed, if possible, as extramural students in families of the same faith near the Institute. Girls and boys were accommodated separately. The management of the facility did not generally accommodate children living with their parents in the city and walking to school in the boarding house, as well as children left with other families by their parents. The consent of the head of the facility was required in order to place a child in another family, additionally, they would also have to inform the National Starost, who could withdraw this permit if it turned out that an extramural student fails to attend school or attends school on an irregular basis. In such cases, the child was placed in the boarding house user or with a family chosen by the Institute. When children were placed in families, the parents' wishes regarding the caregivers were often taken into account. Extramural students were placed only in families with sufficient housing, who ensured proper care and upbringing in the religious, moral and national spirit. The head of the Institute concluded an agreement with the head of the family where the child was to live. In this agreement, the family undertook to accept the child into the family and to bringing them up in a moral, religious and national spirit. The family also committed to provide an adequate room with a bed, as well as healthy and sufficient food and, in the event of illness, adequate care for the child. The families who took care of the deaf children also committed themselves to teaching them order and cleanliness, they would also have to ensure their diligence and regular attendance at school. The principal or teachers appointed by the head of the facility had the right to audit the family and check if they fulfilled their duties. The child support subsidy was established by the National Department.

Children staying at the Institute were provided with medical care. Students were treated by physicians free of charge, the same applied to the medicines prescribed by medical professionals. Treatment costs were covered by the Institute. In the cases of severe illness, which required placing the child in a hospital or clinic, such treatment was decided by the National Starost, after obtaining an opinion from their doctor and the head of the Institute. In the event of an emergency, the head of Institute could order hospitalisation on their own, on the basis of a doctor's opinion, and then ask for immediate approval of the decision by the National Starost. In the event of the death of a student, the principal was obliged to immediately inform the parents or guardians, the Register Office and the National Starost. At the same time, the principal had a duty to organise a funeral, if the child's parents did not take care of that duty. The funeral costs were borne by the persons legally obliged to do so. Every death had to be reported to the School District authorities and the Voivodeship Office. 
With the exception of students walking to school every day, who wore their own clothes and underwear, all the students, both those accommodated in the boarding houses and extramural, were given school uniforms, underwear and shoes, which were supplemented every year or as needed. The children newly admitted to the facility brought required clothes from home and wore them until they were worn down. Clothes were repaired by the Institute in its own workshops. At the request of parents or guardians, who were obliged to provide for children per the provisions of the Civil Code, the principal of the Institute could authorise them to wear their own clothes and shoes, provided that the parents committed themselves to keeping them clean. Such permission could be revoked by the principal if the parents did ensure proper appearance of their child. If the child's family moved to another voivodeship, the parents were obliged to report this fact to the National Starost, who in turn made efforts to place the child in the institution in the relevant municipal association. The transfer of the child to another facility could only take place at the end of the school year. The student could stay in the Institute only if the parents or the municipal association agreed to reimburse the costs. The National Starost had to inform the School District and the Voivodeship Office about the transfer of the student to another facility.

The costs of compulsory education for deaf and speech-impaired children were borne by the local welfare institutions. These included the costs of bringing the child to the facility, the costs of the child's first equipment, funeral expenses and the costs of the child's travel after leaving the institution. Parents or persons obliged under the provisions of the Civil Code to support a child were supposed to reimburse the Institute for the costs of accommodation in a boarding house or lodging, as well as costs of food, clothing, medical care, medicines or hospital care in the amount of 438 złoty per year. If they were unable to cover all or part of these costs, they were covered by the local welfare institutions. The required reimbursements from the welfare institutions and their settlement took place through the relevant district department. The district department was obliged to provide the institution with subsidy in the amount of at least 75 per cent of the actual living expenses of a child placed in the institution. On the other hand, the cost of living for poor Polish children was borne by the National Municipal Association. If a child attending the institution was placed by parents in a private home with the permission of the principal, the costs were reduced to 98 złoty per year. In the case of parents providing clothes for children, the upkeep costs decreased to 60 złoty a year. Persons not belonging to the Pomeranian Municipal Association paid the full upkeep and administrative costs of the Institute in the amount of 803 złoty per year. The National Department could reduce or increase the above rates in relation to the official price index for basic necessities.

The Institute's Rules and Regulations included a full list of clothes that the child had to have. Boys should be equipped with: 2 sets of clothes, 2 pairs of long underwear, 2 coats, 1 headwear, 1 pair of shoes, 1 pair of boots, 1 pair of slippers, 2 pairs of wool stockings, 2 pairs of cotton stockings, 3 shirts, 3 singlets, 3 handkerchiefs, 2 scarves, 1 pair of wool gloves, 1 suspenders, 1 shoe brush, 1 shoe polish brush, 1 comb, 1 toothbrush.

Girls were supposed have: 2 dresses, 2 brassieres, 2 pairs of briefs, 2 skirts, 1 coat, 1 night gown, 3 shirts, 1 headwear, 2 pairs of woollen stockings, 2 pairs of cotton stock- 
ings, 3 aprons, 2 pairs of boots, 1 pair of slippers, 1 pair of garters, 2 scarves, 2 handkerchiefs, 1 pair of woollen gloves, 1 shoe brush, 1 shoe polish brush, 1 comb, 1 toothbrush $^{20}$.

\section{Teaching staff and educators}

In accordance with the provisions of the Rules and Regulations, the Director and the teachers employed in the facility had to have general and special qualifications required by law. When assigning the posts of teachers, the necessity to teach religion to Catholic and Lutheran children should be taken into account ${ }^{21}$.

The principal was responsible for the overall functioning of the institution, including education. The first principal of the Institute was Leonard Retzlaff, who held the position from 1921 to 1926. In addition to managing the facility, he was also involved in preparing teachers to work with children with hearing disability. His classes were attended by all teachers. After the classes, seminars were held at which papers related to the topic were read and discussions were held. The intensity and quality of this type of self-education led to their promotion to the rank of extramural study by the Institute of Special Pedagogy, concluded with a state-mandated examination and qualification for work in a school for the deaf. L. Retzlaff was known for his stringent nature and passion for rules. Supposedly these attributes of character became a direct reason for his resignation from the position of Institute's principal ${ }^{22}$. This is confirmed by J. Kotewicz, who in his monograph stated that the excessive discipline introduced by the principal led the seventh-grade students to sending a letter of complaint to the National Starost Office in 1927. This letter is said to have led to changes on the position of a principal ${ }^{23}$. Franciszek Jereczek took over the post of director of the institution, serving after L. Retzlaff from 1926 to 1933. The last director of the institution before the outbreak of the war was Father Józef Bartel, whose term lasted from 1933 to 1939 . He was born in 1894 as a son of a mailman and lived until 1955 . After completing his seminary in 1923, he was ordained a priest. In 1926 he took up the post of prefect and catechist in the Institute for the Deaf and Speech-Impaired, and from 1933 he served as the head of the facility. He was an ardent supporter of the verbal method of teaching deaf people. He had the qualifications required to teach deaf children. $\mathrm{He}$ graduated from a qualification study organized by PIPS in Warsaw, where he made friends with Maria Grzegorzewska. During the war he was a prisoner in Stutthof and Mathausen concentration camps ${ }^{24}$.

\footnotetext{
${ }^{20}$ Regulamin..., p. 68-70.

${ }^{21}$ Ibidem, p. 68.

22 Ośrodek..., op. cit., p. 16.

${ }^{23}$ KOTEWICZ, J., op. cit.

${ }^{24}$ Ośrodek..., op. cit., p. 5.
} 


\section{PAŃSTWOWY INSTYTUT PEDAGOGIKI SPECJALNEJ.

\section{DY PLOM}

\section{Nauczyciela gluchoniemych \\ Pan .toiclétusti gren}

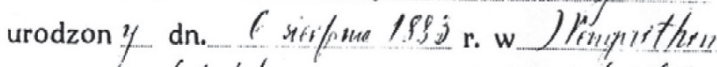

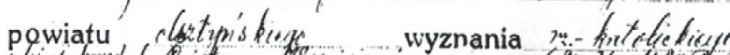

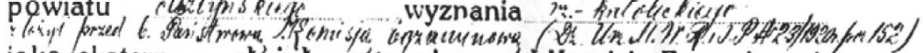

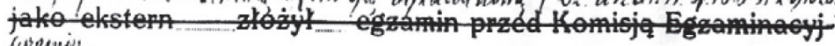
Epronil.

$\mathrm{z}$ wynikiem następującym:

1. Z pracy piśmierinej

2. $Z$ psychologii pedagogicznej

3. $Z$ psychopatologji dziecka $z$ uwzględnieniem podstaw psychopatologji ególnej

4. $Z$ fonstyki i ortofonji fle oxys

5. Z mat dyki nouczania gluchoniemych dirtuge

6. Z dziejow nauczania gluchoniemych etelethe

7. Z lekcyj egzaminacyjnych elofis

8. Ze slöjdu

9. $Z$ gimnastyki, gier $\mathrm{i}$ zabaw

10. $Z$ rysunków

11. Z rozprawy dyplomowei dostatcen mis.

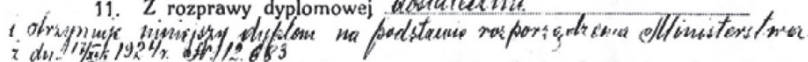

Swiadectwo niniejsze uprawnia do pełnienia obowiązków

nauczyciela Szkół Specjalnych dla dzieci głuchoniemych.

w Warszawie, dnia / Caperefe 1924 r.

Delegat Ministerstwa.

Przewodniczqcy Komisji Egzaminacyjnej

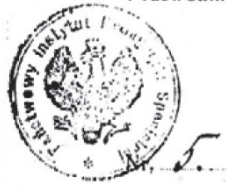

Dyrektor Instytutu

Pedogogiki Specjalnej

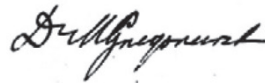

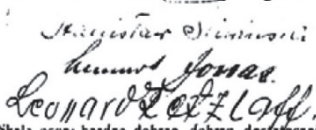

siknla ocent bardzo dobrze, dobrze, dostafecznie, niedostatecznje.

Fig. 1. A diploma of a deaf and speech-impaired children's teacher

Source: Historia Ośrodka Szkolno-Wychowawczego nr 2 dla Gtuchych im. J. Siestrzyńskiego $w$ Wejherowie, Wejherowo 1991, p. 9. 


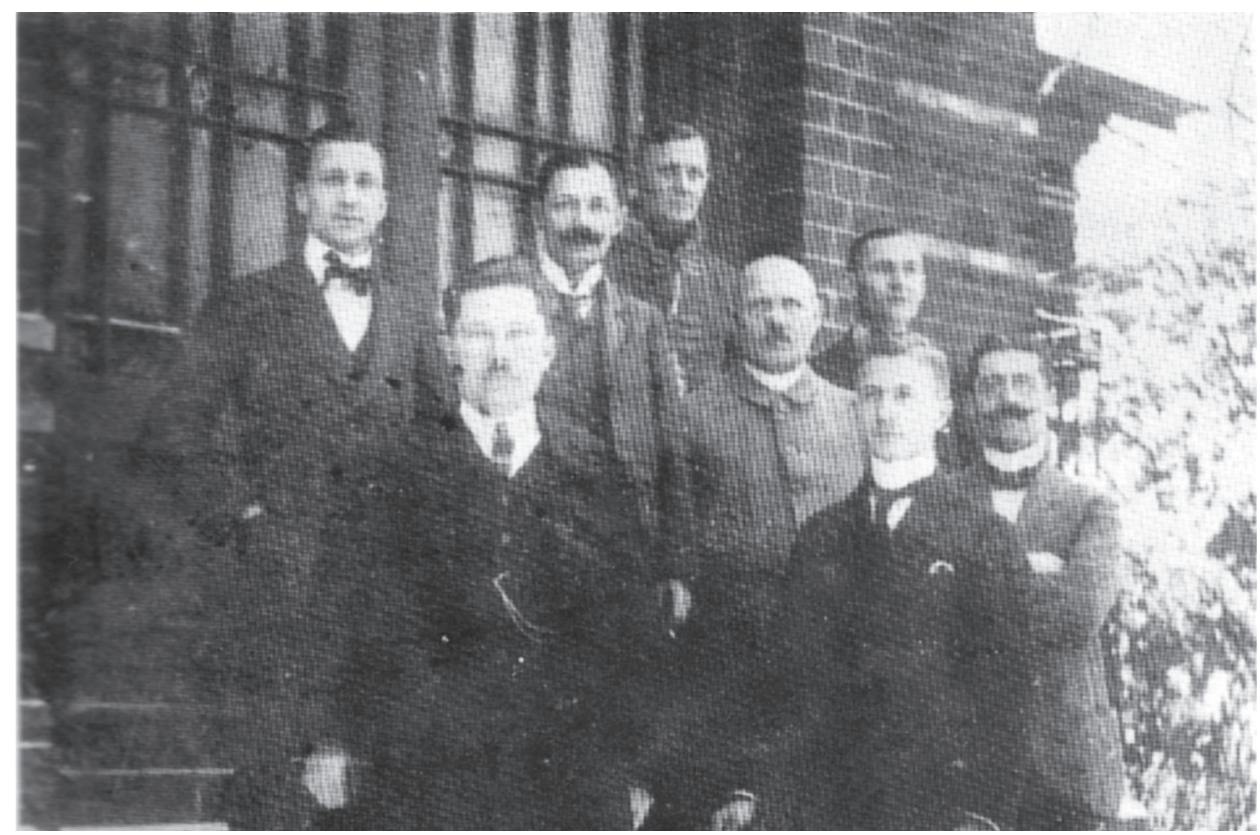

Fig. 2. First staff of the Institution (from the left): B. Lewandowski, T. Lisakowski, L. Retzlaff, J. Idzikowski, W. Wojczyński, E. Fenske, above him J. Maciejewski, J. Bieńkowski

Source: Historia Ośrodka Szkolno-Wychowawczego nr 2 dla Gluchych im. J. Siestrzyńskiego w Wejherowie, Wejherowo 1991, p. 7.

The first teachers in the Department were men, who graduated from German teaching seminars. They were: an Bieńkowski, Edmund Fenske, Józef Idzikowski, Teofil Lisakowski, Jan Maciejewski, Wojciech Wojczyński. Most teachers not only did not know how to work with deaf children, but also had poor command of the Polish language. Therefore, further training in both fields became necessary. L. Retzlaff, the then director of the facility, assumed this responsibility. At the end of the school year 1921/22, Stefania Wojciechowska was employed as the first female teacher ${ }^{25}$.

According to Kalendarz-Informator Polskiego Związku Głuchych, 13 teachers worked in the school year 1932/33 under the direction of Father Józef Bartel. Many teachers and educators were killed during the war. In 1939 Father F. Niklewski, who was the head of the National Social Welfare Institution, was executed in the forests of Piaśnica, and Jan Bieńkowski and Stefania Wojciechowska, teachers of the Institute for the Deaf and Speech-Impaired, died as a result of the repressions of the occupant, as forced labourers ${ }^{26}$. The full list of teachers, educators and staff is presented in Table 1.

\footnotetext{
${ }^{25}$ Ibidem, p. 14.

${ }^{26}$ Ibidem, p. 17.
} 
Table 1. List of teachers, educators and employees

\begin{tabular}{|c|c|}
\hline Teachers & Service period \\
\hline Retzlaff Leonard & 1921-1927, retired \\
\hline Idzikowski Józef & 1921-1937, retired \\
\hline Lisakowski Teofil & 1921-1939 \\
\hline Bieńkowski Jan & $1921-1939$ \\
\hline Lewandowski Brunon & $1921-1939$ \\
\hline Maciejewski Jan & 1921-1939, murdered in 1939 \\
\hline Fenske Edmund & 1921-1939 \\
\hline Wojczyński & 1921-1939 \\
\hline Szuttówna Elżbieta & 20 XI 1930-1939 \\
\hline Tobolski January & 1 IX 1930-30 VIII 1931 \\
\hline Tkaczyk Eugeniusz & 1 IX 1931 \\
\hline Jereczek Franciszek & $\begin{array}{l}1921-1927 \text { as a teacher } \\
1927-1933 \text { as school principal }\end{array}$ \\
\hline Father Bartel Józef & $\begin{array}{l}1927-25 \text { IV } 1933 \text { as a catechist } \\
25 \text { IV } 1933 \text { as school principal }\end{array}$ \\
\hline Kolasińska Aleksa & 1 III 1935 \\
\hline Kotewicz Józef & 1 IX $1937-39$ drafted to the army \\
\hline Kamiński Józef & 16 IX $1937-1939$ drafted to the army \\
\hline Szutta Jan & 1 III 1936-30 VI 1936 \\
\hline Tomaszewska Maria & 1 II 1939 - until the outbreak of war \\
\hline Meyer Brunon & 1924-1939 taken to Puławy \\
\hline Wryczanka Bronisław & 1 IX 1938 \\
\hline Walentówna Bronisława & 1923-1 XI 1929 transferred to Rybnik \\
\hline Educators & Service period \\
\hline Strzyżewski Franciszek & $1921-1939$ \\
\hline Tomaszewski & 1921-1929 \\
\hline Kamiński Władysław & 1 IV 1929-31 V 1935 \\
\hline Derc Józef & 1 III 1937-1939 \\
\hline Educators & Service period \\
\hline Gromadzka Tekla & until 30 VI 1931 \\
\hline Forszpanikówna Helena & 6 VI 1929-31 V 1930 \\
\hline Świeczkowska Magdalena & 1 X 1930-1 V 1933 \\
\hline Zawadzka Wanda & 1 VIII 1931-30 XI 1931 \\
\hline Olszówna Anna & 5 XII 1931-1 V 1933 \\
\hline Piesik Zofia & 1 V 1933-1939 \\
\hline Goniszewska Marta & $1 \mathrm{~V} 1933-1939$ \\
\hline
\end{tabular}




\begin{tabular}{|l|l|}
\hline \multicolumn{1}{|c|}{ Janitors } & \multicolumn{1}{c|}{ Service period } \\
\hline Draszanowski & 1 XI 1929-3 XII 1929 \\
\hline Frankowski Józef & 23 XII 1929-14 I 1930 \\
\hline Tesner Florian & 21 I 1930-22 I 1930 \\
\hline Beyrowski Józef & 1 II 1930-31 V 1936 \\
\hline
\end{tabular}

Source: Kotewicz, J., Historia Zakładu dla Gtuchoniemych. Typescript held by the Educational and Pedagogical Centre no. 2 in Wejherowo.

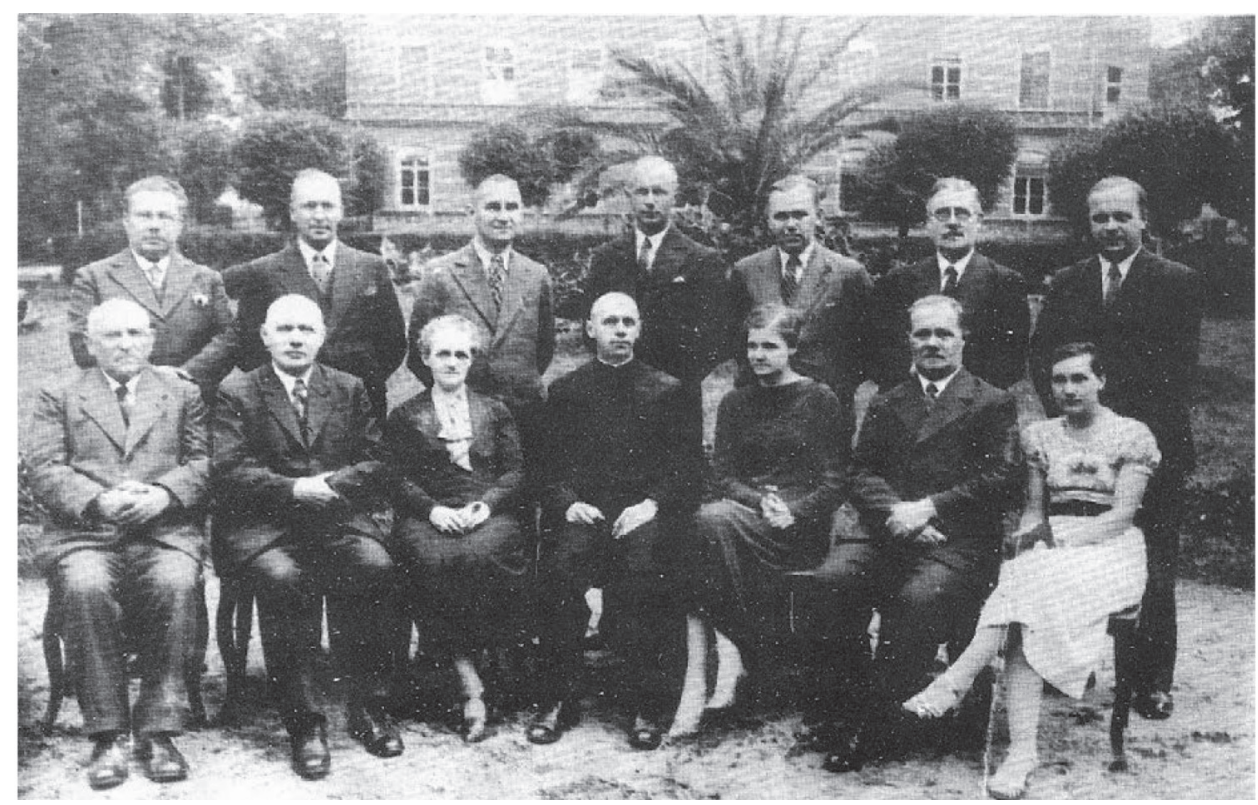

Fig. 3. Teachers from the school in 1935. Standing, from the left: T. Lewandowski, J. Maciejewski, E. Fenske, E. Tkaczyk, J. Bieńkowski, B. Meyer. Sitting, from the left: F. Jereczek, J. Wojczyński, S. Wojciechowska, Father J. Bartel - school principal, A. Kolasińska, J. Idzikowski, E. Szuttówna. Source: Historia Ośrodka Szkolno-Wychowawczego nr 2 dla Gluchych im. J. Siestrzyńskiego w Wejherowie, Wejherowo 1991, p. 17.

\section{Teaching}

In Wejherowo, children studied at the Institute for 8 years. The National Starost could extend the compulsory schooling period; however, no longer than until the end of the school year in which the student turned 18. The condition for obtaining such an extension was the opinion of the teachers' council, according to which the continuation of education gave hope that the student could achieve the assumed educational goal. The tasks of 
the teachers' council included drawing up a curriculum and a schedule of classes together with the principal of the institution, which was submitted to the School District authorities through the National Starost Office. The teachers' council was also responsible for the division of pupils into classes and grades. A rule was adopted that the number of students in one class should be as follows:

- 7 students in each of the articulation grades,

-12 students in each of the lower and middle grades,

-14 students in each of the higher grades.

The curriculum, included in the Rules and Regulations, included the following subjects: religion, reading and writing in Polish, mathematics, geography, nature, physics and chemistry, history of Poland and common history, civic education, Sloyd and crafts, drawing, physical education and games ${ }^{27}$. In the initial period of the facility's operations, the curriculum was based on the experience of other similar schools, German schools in particular. The primary method of teaching was the pure German oral method, derived from the Leipzig school of Samuel Heinicke. Therefore, the curriculum put a strong emphasis on articulation. In years 1923-1933, the curriculum was as follows:

Table 2. Teaching curriculum

\begin{tabular}{|c|c|c|c|c|c|c|c|}
\hline \multirow{2}{*}{ Subject } & \multicolumn{7}{|c|}{ Number of hours in each grade } \\
\hline & $\mathrm{I}$ & II & III & IV & V & VI & VII \\
\hline Religion & 2 & 2 & 2 & 2 & 2 & 2 & 2 \\
\hline $\begin{array}{l}\text { Polish language } \\
\text { articulation } \\
\text { lip reading } \\
\text { speaking } \\
\text { reading } \\
\text { writing }\end{array}$ & $\begin{array}{l}6 \\
- \\
- \\
- \\
-\end{array}$ & $\begin{array}{l}2 \\
2 \\
- \\
2 \\
2\end{array}$ & $\begin{array}{l}2 \\
2 \\
2 \\
2 \\
2\end{array}$ & $\begin{array}{l}2 \\
- \\
3 \\
3 \\
2\end{array}$ & $\begin{array}{l}- \\
- \\
3 \\
3 \\
3\end{array}$ & $\begin{array}{l}- \\
3 \\
3 \\
3 \\
3\end{array}$ & $\begin{array}{l}- \\
3 \\
3 \\
3 \\
3\end{array}$ \\
\hline Mathematics & 4 & 4 & 4 & 4 & 4 & 4 & 4 \\
\hline Natural sciences & - & - & - & - & 2 & 2 & 2 \\
\hline History & - & - & - & - & 2 & 2 & 2 \\
\hline Geography & - & - & - & - & 2 & 2 & 2 \\
\hline Art & 2 & 2 & 2 & 2 & 2 & 2 & 2 \\
\hline Physical education & 2 & 2 & 2 & 2 & 2 & 2 & 2 \\
\hline Workshop classes & 2 & 2 & 2 & 2 & 2 & 2 & 2 \\
\hline Total & 18 & 20 & 22 & 24 & 29 & 30 & 30 \\
\hline
\end{tabular}

Source: Historia Ośrodka Szkolno-Wychowawczego nr 2 dla Gluchych im. J. Siestrzyńskiego w Wejherowie, Wejherowo 1991, p. 22.

\footnotetext{
${ }^{27}$ Regulamin..., op. cit., p. 69.
} 
The Department also took care to prepare the students for professional work, which they could do after leaving the facility. The apprentices were trained in joinery, saddlery, shoemaking, sewing and printing workshops ${ }^{28}$.

The first alumni recalled that there was a very strict discipline in the facility. The students wore uniform clothes. During breaks, they were not allowed to play on their own, as they had to walk in pairs under the supervision of a teacher. The Institute, which was located far from the centre of Wejherowo and surrounded by a tall wall, was the only world for children. The large iron gate was usually closed and leaving the premises required a special pass ${ }^{29}$. The appointment of F. Jereczek to the position of the principal in 1926 led to a relaxation of the existing rules. In 1933, when Father J. Bartel was appointed the principal, the previous ordinances were further relaxed. At that time, children were allowed to play outdoors, the school uniform rules were abolished, boys were allowed to play ball games, football was also allowed, and children were given the opportunity to go out to town more often.

Social life was revived with relaxation of the stringent rules in the Institute. After 1927, deaf boys established a football team that played against other school teams. Teachers J. Idzikowski and E. Szuttówna founded a theatre club, which performed on various occasions. The performances were organized not only in the "lecture hall" built for such purposes in the girls' boarding house, but also in the public hall in Wejherowo. Exhibitions of children's products, which were very popular among the city residents, were also organised often. Moreover, E. Szuttówna organised the first scouting troop in the Institute, which was very popular among the students. An important event for the life of the institution was the establishment of a school newspaper by Mr. Eugeniusz Tkaczyk ${ }^{30}$. After a year he was replaced in the role of editor-in-chief by Ms. Aleksa Kolasińska. The newspaper was published in 1933 under the name of Gazetka Szkolna Wychowanków Szkoty dla Gtuchoniemych w Wejherowie (School Paper of the Students of the School for the Deaf and Speech-Impaired in Wejherowo), with four issues published in a single year. Unfortunately, it was published only for three years. The materials were prepared by the students themselves, and the paper was printed using the fonts of the Educational Institute Printing House in Wejherowo. The paper played an important didactic and educational function, as it encouraged readership, enriched the education process, inspired students to describe their own experiences ${ }^{31}$. The issue no. 5 of 1934 featured a letter from Leokadia Gabrychówna, a former student of the Institute, addressed to the paper's editorial office. It shows what kind of memories stayed with the students: "I wanted to write this letter to my beloved School Paper for a long time. Unfortunately, I had to postpone writing it until now. In mid-January this year, I got my hands on the School Paper for the first time. I did

\footnotetext{
${ }^{28}$ NAGGB, Fonds 223, National Social Welfare Organisations in Wejherowo, sign. 12, c. 81-83.

${ }^{29}$ Historia..., op. cit., p. 16.

${ }^{30}$ KOTEWICZ, J., op. cit.

${ }^{31}$ Ośrodek..., op. cit., p. 8.
} 


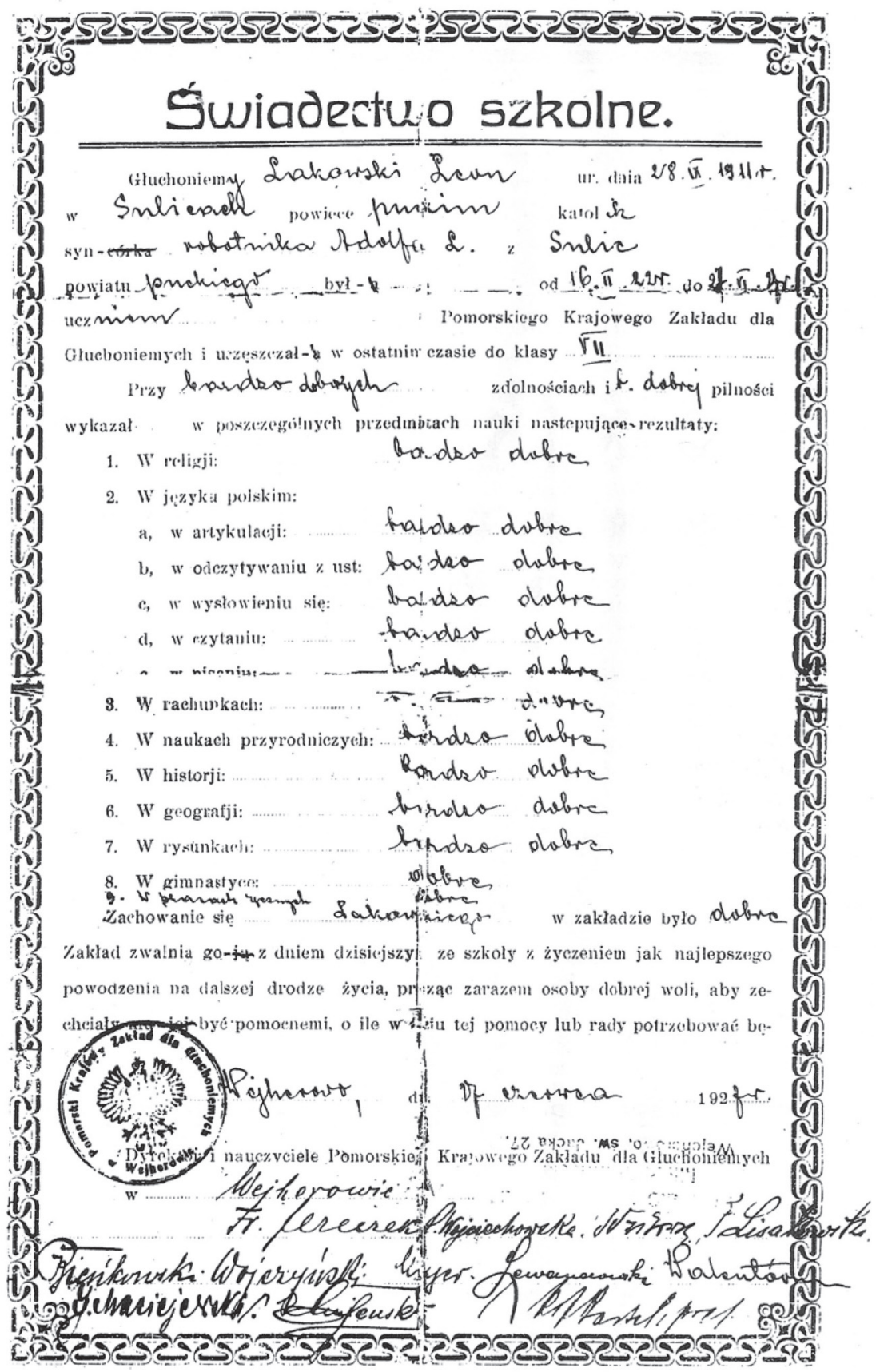

Fig. 4.

Source: Historia Ośrodka Szkolno-Wychowawczego nr 2 dla Gtuchych im. J. Siestrzyńskiego w Wejherowie, Wejherowo 1991, p. 13. 
not hesitate to read it with great interest. I'm very satisfied and I'm very happy that I can learn a lot about my beloved school. When I am reading, I feel like I am with my friends at school again. I am pleased to remember the moments I experienced at school, the moments I will never forget. I will be grateful to Father Principal and my Teachers for their care during my time at the School for the Deaf and Speech-Impaired. Thank you very much for sending free copies of the paper to the Catholic Society for the Deaf in Czersk for the purpose of providing it to the local members. Kindest regards for everybody at school, especially Ms. Wojciechowska, who taught me well ${ }^{32}$." The source materials collected by the Educational and Pedagogical Centre feature memories of students and teachers, which were included in the typescript written by J. Kotewicz, one of the Institute's teachers, and partially published in the anniversary publication on the history of the institution. These memories describe education and everyday life in the institution, while at the same they also serve as evaluation of the functioning of the institution and the quality of the teaching staff. Klara Wittkowa, one of the students, recalls her school education as follows:

In 1921 I was deaf after a serious illness and at the age of 6 I was admitted to a school for the deaf, which was newly opened at that time [...]. The school year started on the 1st of September 1921. Shortly after my arrival, there was an official opening ceremony, preceded by the Holy Mass and the consecration of the school buildings by Father W. Dąbrowski from Wejherowo, in the presence of representatives of the Voivodeship authorities and teaching staff, with commemorative photographs taken. When I started my first school year, I was the youngest one among my friends and classmates. We studied in a large, spacious room next to the office. Our first-grade teacher and educator was the first headmaster of the school, Recław Leonard, a man with a harsh face and gaze, then Lewandowski. First grade education was based solely on articulation[...], then on pronunciation of words, in the second grade we moved on to the formation of sentences. It was quite boring for us, and for the teacher it was the most difficult, as it required a lot of kindness and sacrifice. It wasn't until the third grade that I started to be interested in learning the everexpanding and broader curriculum, so I started learning with more and more enthusiasm, achieving better and better results. To this day, I remember the arrival of Stanisław Wojciechowski, the President of Poland, to Wejherowo and his arrival at the Pomeranian National Institute for the Deaf and Speech-Impaired. On this solemn day, we were told to form a line at the main gate of the Institute, we were in the third grade. At the very beginning of the welcome given to our dignified guest, I received a sign from our class teacher and I came up to him dressed in traditional Krakow outfit, with a bouquet of flowers in my hands. I shouted three times: "Long live the President of the Republic of Poland". Then Henryk Monikowski, who was older than me, recited a poem in honour of our guest. In higher grades, the most interesting subject for me was the history of Poland and reading. I listened with great passion to the stories about Polish kings, their reign and battles told by our teacher. I learned this almost by heart. In order to help us remember, there was

${ }^{32}$ Historia..., op. cit., p. 24. 
a board with Polish kings hanging on the wall of the classroom. Various paintings were also hanging on the walls, including the depictions of Polish poets, as well as pictures of living nature, such as plants, herbs, mushrooms, etc. In general, drawing was my favourite activity. The drawing classes were led by Fenske, then by Jereczek. On sunny days we often went to the forest with the teacher, holding drawing blocks and pencils in our hands, where we drew birch trees, mushrooms and forest views. Some students exhibited great artistic talent, and the most talented among them was Sommerfeld, who drew pencil portraits of Polish poets, including J. Słowacki, H. Sienkiewicz and other writers, receiving praise from visitors. Another favourite activity of mine were all kinds of arts and crafts, including embroidery, crocheting, making nets and napkins, etc. All of them were very beautiful, which clearly testified to the ability of deaf girls and boys, who made sculptures from wood and clay, as well as small tapestries and other interesting, delightful exhibits under the direction of J. Idzikowski in the case of boys and St. Wojciechowska in the case of girls. The exhibits were presented on an exhibition in Wejherowo, which attracted a lot of public interest and enjoyed great demand. After a few days of exhibiting, a sale was held and almost all of the exhibits were sold on the very first day. We also had gymnastics with teacher Walentynówna, we exercised outside, in the school's yard, and in winter we went to the local Jan Sobieski gymnasium in the afternoon. In general, mathematics was the easiest subject. Nearly all students were able to solve the required tasks. In my eighth grade, mathematics was taught by Mr. Bieńkowski, who taught us percentages and fractions, something which was taken from the secondary school curriculum. The Institute, which was surrounded by a high wall and an iron gate, was usually closed, and children could go to the city only if they could produce the so rarely handed out pass. The common walks for children supervised by the boarding school supervisor took place every Sunday exclusively in the local park, we very rarely went to the city. After Mr. Jereczek took up the position of director after Mr. Recław, the situation changed a little. Much to their joy, children were allowed to visit the city more often. For a few years, while staying at school, I had an opportunity to learn about the character of my tutor, Stefania Wojciechowska. She was a woman who was sincerely committed to the cause of the deaf people, who did her best to enrich the lives of her students with education and instil the sense of patriotism. She severely punished laziness and rewarded good academic performance with gifts in the form of reading books. Before the end of the school year in the eighth grade, she gave everybody a commemorative historical book titled Wieczory pod lipa (Evenings under the lime tree). During the school period, Father Bishop of Okoniewski from Pelplin and Cardinal Hlond from Poznań were the most distinguished guests at the Institute. During their visit, we were gathered in the assembly hall where some classes were taught at the school tables. Our class also took part. Every year, graduates of the local Teachers' School also visited our school and, as future young teachers, they listened attentively to our classes, claiming that teaching deaf is extremely difficult and that it did not encourage them to become teachers for the deaf. From time to time, our Institute doctor, Dr Sokołowski visited our class - we all knew him, as we were often examined in his office. From time to time, performances were organised by students under the direction of Ms. Wojciechowska and Mr. Idzikowski. The most pleasant memory of mine was receiving a gift from the 
Pomeranian Voivode - a painting depicting the Queen of the Polish Crown, which I received for my diligence and good behaviour. The painting still remains in my possession today. On the day I graduated the school in June 1929, during the graduation ceremony held in the lecture hall, Principal Jereczek praised the best students during his speech. My name was also mentioned among them, and I saw the happy faces of my parents among the invited guests, parents and relatives of other students ${ }^{33}$.

It is worth noting that the Institute for the Deaf and Speech-Impaired in Wejherowo also took care of its former students in their later life. To this end, the facility kept a detailed record of students leaving the institution. There is a provision in the Rules and Regulations of the Institute: "For adult deaf and speech-impaired men and women, who, due to their disability, were unable to earn their own living, and for those who are threatened with moral decline, a shelter should be set up at the facility, managed by the head of the Institute. The upkeep costs shall be paid by municipalities in the amount of 180 zlotys per annum. Admission to the shelter is decided upon by the National Starost upon request of the municipality. Once a year, during summer holidays, two-day meetings of deaf and speech-impaired people living in Pomerania shall be held at the Institute for the Deaf and Speech-Impaired. These meetings are aimed at educating and providing moral guidance to these people. The meetings are headed by the director of the Institute, together with a catechist and a teaching council. During the meetings, the Institute shall offer accommodation and board free of charge. For the purpose of pastoral ministry, a catechist shall organise conventions of deaf and speech-impaired adults living in Pomerania ${ }^{34}$." Unfortunately, no information was found in the analysed source material that would confirm the implementation of the provisions of the Rules and Regulations. That is why further research is necessary, especially regarding the interwar period, which may allow for a more detailed presentation of the institution described above, especially its teaching and educational activity, as well as its effectiveness and pedagogical staff.

\section{Works cited:}

\section{Archive sources}

National Archive in Gdańsk, Gdynia Branch:

Fonds 223: National Social Welfare Organisations in Wejherowo, sign. 3, 9, 12.

Fonds 72: School Inspectorate in Wejherowo in years [1911] 1918-1939, sign. 343.

Printed sources

"Regulamin dla Pomorskiego Krajowego Zakładu dla Głuchoniemych w Wejherowie", Dziennik Urzędowy Województwa Pomorskiego, issue 15, year V, Torun, 13. VI, 192.

\footnotetext{
33 KOTEWICZ, J., op. cit.

${ }^{34}$ Regulamin..., op. cit., p. 70.
} 
KOTEWICZ J., Historia Zakładu dla Gluchych w Wejherowie. Typescript held by the Educational and Pedagogical Centre no. 2 Library in Wejherowo.

Historia Ośrodka Szkolno-Wychowawczego nr 2 dla Gtuchych im. J. Siestrzyńskiego w Wejherowie, Wejherowo 1991.

Ośrodek Szkolno-Wychowawczy $n r 2$ dla Niestyszących im. J. Siestrzyńskiego $w$ Wejherowie, Wejherowo 2001.

\section{Magazines}

"Statystyka", Nauczyciel Głuchoniemych i Niewidomych 1928, issue 2.

TUŁODZIECKI W., "Stan i potrzeby szkolnictwa dla głuchoniemych w Polsce", Nauczyciel Gtuchoniemych i Niewidomych, 1932, issue 1.

HELLMANN J., "Stan i potrzeby szkolnictwa specjalnego w Polsce”, Szkoła Specjalna, 1924/25, issue 1.

RYLL H., "Stan szkolnictwa specjalnego w Polsce w ostatnim pięcioleciu", Szkoła Specjalna 1938/39, issue 15 , p. 153-155.

Originally published in "Biuletyn Historii Wychowania", 2016, vol. 35, pp. 35-52 
